\title{
Human Reliability Assessment dengan Metode Human Error Assessment and Reduction Technique pada Operator Stasiun Shroud PT. X
}

\author{
Dian Mardi Safitri ${ }^{1 *}$, Ayu Rachma Astriaty ${ }^{2}$, Nataya C. Rizani ${ }^{3}$ \\ $1 *, 2,3)$ Laboratorium Desain Sistem Kerja dan Ergonomi, Program Studi Teknik Industri, \\ Universitas Trisakti \\ Jl. Kyai Tapa no 1 Jakarta Barat 11440. \\ email : dianmetrisakti.ac.id, dianmardi.safitri@gmail.com
}

\begin{abstract}
Human realibility is a big issue because it concerns with human failure rates that depend on three main factors, namely intrinsic, work environment, and stress. PT. X is a supplier for PT. LG Indonesia manufacturing products made from plastics. Human Realibility Assesment is conducted using HEART methods (Human Error Assessment and Reduction Technique). In the first phase, task analysis on operators' activities is done using Hierarchical Task Analysis (HTA). The largest Human Error Probability was found when Operator No. 1 did not insert the flash side carefully. The value of this probability is 0.53424 which is then concluded as the main cause to Shroud defectives, which results in customer penalyzing the company.

Keywords: Human Error, Human Reliability Assessment, Hierarchical Task Analysis, Human Error Assessment and Reduction Technique

Abstrak

Persoalan keandalan manusia adalah perihal besar. Tingkat kegagalan manusia tergantung pada banyak faktor yang mana dapat dikelompokkan dibawah tiga faktor utama yaitu intrinsic, lingkungan kerja, dan tekanan atau stress. PT. X merupakan salah satu perusahaan supplier utama untuk PT. LG Indonesia dalam pembuatan produk komponen plastik. Human Reliability Assesment dilakukan dengan menggunakan metode HEART (Human Error Assessment and Reduction Technique). Pada tahapan awal dilakukan analisis terhadap tugas yang harus dilakukan operator dengan menyusun Hierarchical Task Analysis (HTA) sebagai tahapan awal dari metode HEART. Berdasarkan perhitungan diperoleh nilai Human Error Probability terbesar ada pada jenis kesalahan tidak menyisip sisi flash dengan hati-hati yang dilakukan oleh operator satu yaitu dengan nilai 0.53424. Faktor inilah yang disimpulkan sebagai penyebab utama cacatnya produk shroud yang mengakibatkan perusahaan mengalami kerugian akibat penalti dari konsumen.
\end{abstract}

Kata Kunci: Human Error, Human Reliability Assessment, Hierarchical Task Analysis, Human Error Assessment and Reduction Technique

\section{Pendahuluan}

Love dan Josephson (2004) mendefinisikan $h u$ man error sebagai kegagalan dari manusia untuk melakukan tugas yang telah didesain dalam batas ketepatan, rangkaian, atau waktu tertentu. Sedangkan Peters (2006) menyebutkan bahwa human error adalah suatu penyimpangan dari

\footnotetext{
* Korespondensi Penulis
}

standar performansi yang telah ditentukan sebelumnya sehingga menyebabkan adanya penundaan akibat dari kesulitan, masalah, insiden, dan kegagalan. Human error merupakan kesalahan dalam pekerjaan yang disebabkan oleh ketidaksesuaian atas pencapaian dengan apa yang diharapkan.

PT. X merupakan salah satu perusahaan supplier utama komponen plastik kulkas untuk PT 
LG Indonesia. PT LG Indonesia memberlakukan penalti pada PT. X untuk setiap komponen yang cacat. Produk yang menjadi objek penelitian adalah komponen Shroud, yang berfungsi sebagai penampang kipas dan pencegah terjadinya bunga es pada kulkas. Dibandingkan dengan komponen lain, shroud adalah komponen yang paling tinggi jumlah cacat produknya.

Dari pengamatan awal, diketahui bahwa manusia mempunyai peranan yang penting di stasiun ini. Tugas operator pada stasiun ini tidak hanya untuk mengambil shroud dari mesin injeksi tetapi juga merakit komponen-komponen pada motor shroud, melakukan inspeksi produk, hingga memasukkan produk jadi Shroud ke dalam kardus packaging. Berhubungan dengan kinerja manusia dalam menjalankan tugas di stasiun ini, sering didapati adanya kesalahankesalahan yang disebabkan karena human error.

Selain itu beban kerja yang dipegang oleh operator dirasa cukup besar dengan operator harus memastikan bahwa setiap bidang motor Shroud yang keluar dari mesin injeksi harus diperiksa terlebih dahulu sisi-sisinya dan dirapikan dengan mengikis sisinya secara tepat. Kemudian operator harus merakit komponenkomponen pendukung motor Shroud dengan pas dan tepat serta menggunakan kode komponen yang tepat.

Diketahui bahwa operator bekerja dalam 3 shift, untuk shift 1 dari jam 07.00-15.00, untuk shift 2 dari jam 15.00-23.00, dan untuk shift 3 jam 23.00-07.00 dengan waktu istirahat pada masing-masing shift yaitu selama 45 menit. Tetapi tidak jarang jika para operator diharuskan untuk lembur karena produksi yang harus selesai tepat waktu untuk segera dikirimkan ke PT. LG Indonesia, karena perusahaan tersebut adalah perusahaan manufaktur yang terus-menerus menghasilkan produk kulkas setiap harinya.

Tujuan dari penelitian ini adalah untuk mengidentifikasi kemungkinan - kemungkinan kesalahan operator yang terjadi pada stasiun kerja shroud dan mengukur keandalannya dari setiap kegiatan dengan menggunakan metode Human Reliability Assessment.

\section{Metode Penelitian}

Human Reliability Assesment (HRA) merupakan suatu pendekatan yang digunakan untuk mengetahui tingkat keandalan manusia yang menjadi anggota dari suatu sistem.

Keandalan manusia didefinisikan sebagai suatu probabilitas performansi seseorang akan be- bas dari kesalahan selama jangka waktu tertentu. Keandalan Manusia juga dapat didefinisikan sebagai probabilitas suatu aktivitas yang dilakukan manusia berhasil sesuai dengan tujuannya dalam suatu sistem operasi pada periode waktu yang ditentukan.

Tujuan dari HRA adalah mengidentifikasikan area dengan resiko tinggi, mengukur keseluruhan resiko dan mengindikasikan di mana dan bagaimana perbaikan seharusnya dibuat untuk sistem.

Bell (2009) menyebutkan bahwa untuk melakukan penilaian keandalan manusia $(\mathrm{Hu}$ man Reliability Assessment - HRA) dapat dipakai metode kualitatif dan kuantitatif. Dengan metode ini, dapat dilakukan penilaian mengenai kontribusi manusia terhadap risiko. Ada banyak dan beragam metode yang tersedia untuk HRA. Industri yang memiliki risiko tinggi telah mengembangkan metodenya sendiri, mengingat risiko sangat spesifik yang mereka miliki.

Selanjutnya dilakukan pengukuran probabilitas terjadinya error dengan metode HEART. Metode HEART adalah teknik yang digunakan dalam bidang penilaian keandalan manusia (HRA/Human Reliability Assessment), untuk tujuan mengevaluasi kemungkinan kesalahan manusia terjadi di seluruh penyelesaian tugas tertentu.

Metode HEART didasarkan pada prinsip bahwa setiap kali tugas dilakukan ada kemungkinan gagal dan bahwa kemungkinan ini dipengaruhi oleh satu atau lebih EPC (Error Producing Condition), misalnya: gangguan, kelelahan, kondisi sempit dan lain-lain. Faktor-faktor yang memiliki pengaruh yang signifikan terhadap kinerja ditunjukkan dengan nilai HEP terbesar. Kondisi ini kemudian dapat diterapkan untuk "best-case scenario" perkiraan probabilitas kegagalan di bawah kondisi ideal untuk kemudian mendapatkan kesempatan kesalahan akhir.

Angka ini membantu dalam komunikasi kemungkinan kesalahan dengan analisis risiko yang lebih luas atau kasus keselamatan. Dengan pertimbangan EPCs, metode HEART juga memiliki efek tidak langsung menyediakan berbagai saran tentang bagaimana keandalan dapat ditingkatkan dari sudut pandang ergonomis. Metode HEART didasarkan pada sejumlah hal, yaitu:

1. Keandalan manusia dasar tergantung pada sifat generik dari tugas yang akan dilakukan.

2. Dalam kondisi 'sempurna', tingkat kean- 
dalan akan cenderung dicapai secara konsisten dengan kemungkinan nominal yang diberikan dalam batas probabilistik.

3. Mengingat bahwa kondisi yang sempurna tidak ada dalam segala situasi, keandalan manusia diprediksi dapat menurunkan sebagai fungsi dari sejauh mana identifikasi Error Producing Conditions (EPCs) dapat berlaku.

Dalam penelitian yang menggunakan metode HEART, peran pakar/ahli sangat penting. Pakar yang dilibatkan dalam penelitian ini adalah Manager Human Resources and Development (HRD yang telah bekerja di PT.X selama 11 tahun dengan karir awal sebagai operator di stasiun kerja shroud).

Berikut adalah tahapan-tahapan yang dilakukan dalam perhitungan Human Error Probability (HEP) dengan menggunakan metode HEART (Human Error Assessment and Reliability Technique) :

1. Menentukan tipe task dari kemungkinan error yang terjadi (HEP) yang diperoleh dari tabel HEART Generic Categories

Setelah membuat hierarki dari analisa tugas yang ada, maka langkah berikutnya adalah menentukan nilai nominal human unreliability dengan membandingkan jenis task dengan kategori task yang terdapat pada HEART Categories dan mendiskusikannya dengan pakar (lihat tabel 1).

2. Hasil Penilaian HEART

Tahap selanjutnya adalah dengan pemilihan dan penilaian EPC oleh pekerja. Pada tahap ini diadakan diskusi dengan pakar untuk memilih EPC (lihat tabel 2) yang dapat menyebabkan error bagi pekerjaan yang dianalisa, kemudian dilakukan penilaian terhadap EPC tersebut, seberapa besar probabilitas EPC tersebut dapat menyebabkan error atau kegagalan. Kemudian penilaian masing-masing EPC tersebut dikalikan dengan total HEART effect yang didapatkan pada tabel 2.

Hasil kali tersebut menghasilkan assessed effect yang kemudian dijumlahkan menjadi total assessed effect. Nilai total assessed effect ini dikalikan dengan nilai HEART Generic Categories (lihat tabel 1) sesuai dengan jenis pekerjaannya menghasilkan probability of failure yang menunjukkan kemungkinan kegagalan dari suatu pekerjaan. HEART Generic Categories didapatkan dengan mengkategorikan task ke dalam beberapa kelompok yang terdapat pada tabel 1 .
Tabel 1: Generic Task Dalam Metode HEART

\begin{tabular}{|c|c|c|c|}
\hline Kode & Generic Task & $\begin{array}{l}\text { Nilai } \\
\text { Human } \\
\text { Unreli- } \\
\text { ability }\end{array}$ & Range \\
\hline (A) & $\begin{array}{c}\text { Pekerjaan/task yang benar-benar } \\
\text { asing/tidak dikuasai, dilakukan } \\
\text { pada suatu kecepatan tanpa } \\
\text { konsekuensi yang jelas }\end{array}$ & 0.55 & $(0.35-0.97)$ \\
\hline (B) & $\begin{array}{l}\text { Mengubah atau mengembalikan } \\
\text { sistem ke keadaan yang baru atau } \\
\text { awal dengan satu upaya tunggal } \\
\text { tanpa pengawasan atau prosedur }\end{array}$ & 0.26 & $(0.14-0.42)$ \\
\hline (C) & $\begin{array}{l}\text { Pekerjaan yang kompleks dan } \\
\text { membutuhkan tingkat pemahaman } \\
\text { dan keterampilan yang tinggi }\end{array}$ & 0.16 & $(0.12-0.28)$ \\
\hline (D) & $\begin{array}{c}\text { Pekerjaan yang cukup sederhana, } \\
\text { dilakukan dengan cepat atau } \\
\text { membutuhkan sedikit perhatian }\end{array}$ & 0.09 & $(0.06-0.13)$ \\
\hline (E) & $\begin{array}{l}\text { Pekerjaan yang rutin, terlatih, dan } \\
\text { memerlukan tingkat keterampilan } \\
\text { yang rendah }\end{array}$ & 0.02 & $(0.007-0.045)$ \\
\hline$(\mathrm{F})$ & $\begin{array}{l}\text { Mengembalikan atau menggeser } \\
\text { sistem ke kondisi awal atau baru } \\
\text { dengan mengikuti prosedur, } \\
\text { dengan beberapa pemeriksaan }\end{array}$ & 0.003 & $\begin{array}{c}(0.0008- \\
0.007)\end{array}$ \\
\hline (G) & $\begin{array}{c}\text { Pekerjaan yang sudah } \\
\text { familiar/dikenal, dirancang dengan } \\
\text { baik, merupakan tugas rutin yang } \\
\text { terjadi beberapa kali per jam, } \\
\text { dilakukan berdasarkan standard } \\
\text { yang sangat tinggi oleh personel } \\
\text { yang telah terlatih dan } \\
\text { berpengalaman dengan waktu } \\
\text { untuk memperbaiki kesalahan } \\
\text { yang potensial }\end{array}$ & 0.0004 & $\begin{array}{c}(0.00008- \\
0.09)\end{array}$ \\
\hline$(\mathrm{H})$ & $\begin{array}{c}\text { Menanggapi perintah sistem } \\
\text { dengan benar bahkan ada sistem } \\
\text { pengawasan otomatis tambahan } \\
\text { yang menyediakan interpretasi } \\
\text { akurat }\end{array}$ & 0.00002 & $\begin{array}{c}(0.000006- \\
0.009)\end{array}$ \\
\hline$(\mathrm{M})$ & Tidak ada keadaan seperti di atas & 0.03 & $(0.008-0.11)$ \\
\hline
\end{tabular}

Tabel 2 memperlihatkan nilai EPC (Error Producing Conditions) yang ada di dalam penggunaan Metode HEART.

\section{Hasil dan Pembahasan}

Stanton (2005) menyebutkan bahwa Hierarchical Task Analysis (HTA) digunakan untuk mewakili hubungan antara tugas-tugas dan subtasks. Ini catatan persyaratan sistem dan bagaimana tersebut dapat dicapai, termasuk urutan di mana tugas-tugas dan subtasks dapat mengambil tempat. Hal ini dapat direkam dalam bentuk tabular dan / atau pictorially. Jika direkam pictorially itu menyerupai sebuah pohon dengan cabang-cabang dan cabang-cabang sub seperti yang diperlukan.

Task analysis adalah suatu metode untuk menganalisis pekerjaan manusia, apa yang dikerjakan dengan apa mereka bekerja dan apa yang harus mereka ketahui. Contohnya : apa saja tugas yang dilakukan untuk membersihkan rumah. Task analysis ini merupakan proses menganalisa tentang cara peng- 
Tabel 2: Generic Task Dalam Metode HEART

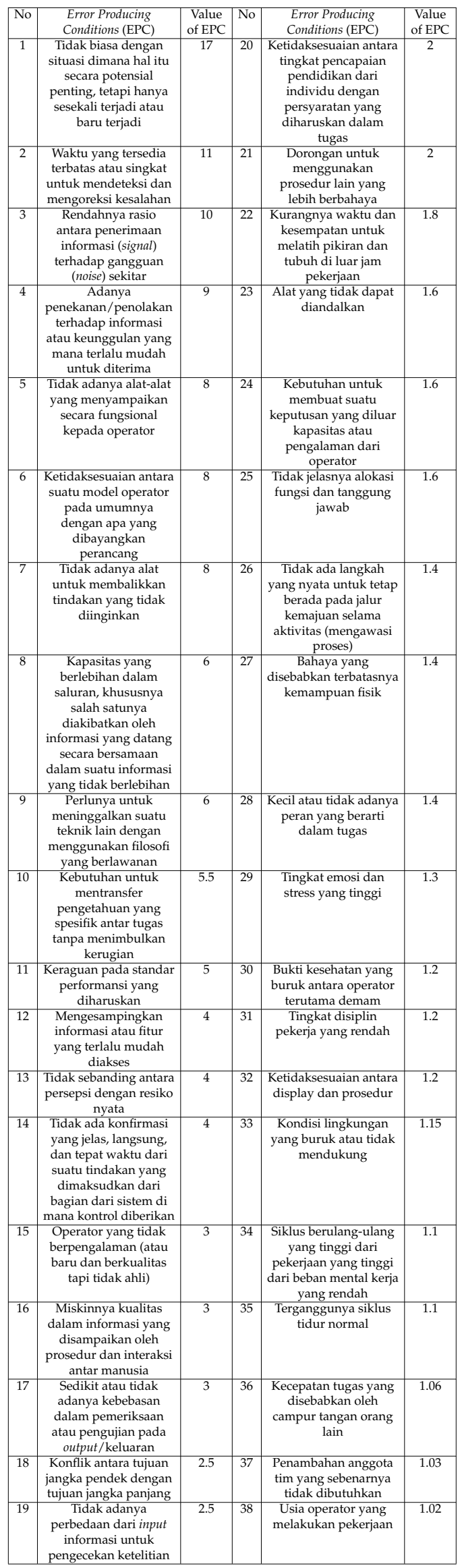

guna dalam mengerjakan, menyelesaikan dan bereaksi terhadap tugas dari suatu sistem dan hal-hal yang ingin diketahui oleh pengguna. Dix (2009) menyebutkan bahwa fungsi dari task analysis adalah untuk menyediakan informasi yang berguna dalam pengambilan keputusan desain serta sebagai dasar untuk mengevaluasi desain dari sistem.

Identifikasi kegagalan kerja dianalisa berdasarkan elemen pekerjaan yang telah disebutkan. Identifikasi kegagalan kerja dilakukan dengan membandingkan data hasil pengamatan yang sudah dirangkum dalam bentuk Hierarchy Task Analysis (HTA) dengan data Point Check yang terdapat pada pabrik yang akan menghasilkan Possible Error (Kemungkinan Kegagalan). Aktivitas-aktivitas yang menyebabkan kemungkinan kegagalan ditandai dengan huruf miring pada HTA di atas. Setelah dicocokkan antara HTA dengan data Point Check, maka dilanjutkan dengan menerangkan akibat atau konsekuensi dari kegagalan tersebut. Berdasarkan Possible Error ini akan diidentifikasi besarnya nilai probability of failure (nilai kemungkinan kegagalan) dengan menggunakan metode HEART (Human Error Assessment and Reliability Technique).

Tabel 3 menampilkan identifikasi kegagalan operator dalam pembuatan Shroud.

Contoh cara perhitungan HEP dengan menggunakan metode HEART pada aktivitas tidak memperhatikan warna harus sesuai dengan approval adalah:

1. Menentukan generic task

Generic Task yang dapat dikelompokkan dengan task ini adalah (E) yaitu pekerjaan yang rutin, terlatih, dan memerlukan tingkat keterampilan yang rendah. Dengan nilai Nominal Human Reliability adalah 0.02 (lihat tabel 1).

2. Menentukan EPC (Error Producing Condition)

Kemudian dipilih Error Producing Conditions yang sesuai dengan keadaan dan dituliskan nilai Total HEART Effect nya sesuai dengan tabel. EPC ini dipilih berdasarkan wawancara dengan expert/pakar.

3. Menentukan Assessed Proportion-nya dengan range 0-1.

Penentuan Assessed Proportion ini berdasarkan kuesioner dan hasil wawancara dengan expert/pakar dan operator yang bersangkutan

4. Menghitung Hasil HEP (Human Error Probability)

Selanjutnya hitung Assessed Effect-nya, mi- 
Tabel 3: Identifikasi Kegagalan Operator Pembuatan Produk Shroud

\begin{tabular}{|c|c|c|}
\hline Tasks & Possible Error & Akibat \\
\hline \multirow{9}{*}{ Pemeriksaan bidang shroud } & $\begin{array}{l}\text { Tidak memperhatikan warna yang harus sesuai } \\
\text { dengan approval }\end{array}$ & $\begin{array}{l}\text { Warna bidang Shroud tidak sesuai dengan pe- } \\
\text { sanan dan ketentuan }\end{array}$ \\
\hline & Tidak memeriksa apa ada yang short material & Shroud mengalami cacat, kualitas berkurang \\
\hline & Tidak memeriksa adanya silver & Shroud mengalami cacat, kualitas berkurang \\
\hline & Tidak memeriksa adanya legok/sink mark & $\begin{array}{l}\text { Shroud mengalami cacat, kualitas berkurang, } \\
\text { shroud akan sulit dirakit dengan komponen lain } \\
\text { karena ada bidang yg tidak pas (legok) }\end{array}$ \\
\hline & Tidak memeriksa adanya belang & Shroud mengalami cacat, kualitas berkurang \\
\hline & Tidak memeriksa adanya baret (scratch) & Shroud mengalami cacat, kualitas berkurang \\
\hline & $\begin{array}{l}\text { Tidak memeriksa adanya wild line (sambungan ba- } \\
\text { han) }\end{array}$ & Shroud mengalami cacat, kualitas berkurang \\
\hline & $\begin{array}{l}\text { Tidak menyisip area flash menggunakan pisau } \\
\text { dengan hati-hati }\end{array}$ & $\begin{array}{l}\text { Membahayakan operator dalam memegang } \\
\text { shroud karena area flash umumnya tajam, terjadi } \\
\text { noise pada saat kipas berputar (ada flash di sekitar } \\
\text { area fan), shroud akan sulit dirakit dengan kom- } \\
\text { ponen lain, dapat melukai tangan operator, bisa } \\
\text { terjadi overcut (bidang coak), ada area flash yang } \\
\text { belum disisip }\end{array}$ \\
\hline & Tidak memeriksa apa ada area yang overcut & $\begin{array}{l}\text { Menyebabkan cacat coak, shroud tidak dapat di- } \\
\text { rakit komponen lain karena tidak pas }\end{array}$ \\
\hline \multirow{3}{*}{$\begin{array}{l}\text { Pemasangan foam pada } \\
\text { sisi bidang shroud }\end{array}$} & Tidak memeriksa apakah foam mengelupas & $\begin{array}{l}\text { Menyebabkan kemungkinan timbulnya bunga es } \\
\text { pada kulkas, kualitas berkurang }\end{array}$ \\
\hline & Tidak memeriksa apakah foam tertarik & $\begin{array}{l}\text { Menyebabkan kemungkinan timbulnya bunga es } \\
\text { pada kulkas, kualitas berkurang }\end{array}$ \\
\hline & $\begin{array}{l}\text { Tidak memberi tanda marking inisial operator, } \\
\text { tanggal, dan shift }\end{array}$ & Menyulitkan dalam memasukkan data produksi \\
\hline \multirow{16}{*}{$\begin{array}{l}\text { Perakitan komponen } \\
\text { pendukung }\end{array}$} & $\begin{array}{l}\text { Tidak memeriksa tipe komponen sesuai dengan } \\
\text { Shroud yang akan dibuat }\end{array}$ & $\begin{array}{l}\text { Kualitas Shroud menurun, Produk Shroud tidak } \\
\text { terpasang sesuai dengan pesanan konsumen }\end{array}$ \\
\hline & Merakit komponen tidak sesuai dengan urutan & $\begin{array}{l}\text { Kualitas Shroud menurun, Produk Shroud tidak } \\
\text { terpasang sesuai dengan pesanan konsumen }\end{array}$ \\
\hline & $\begin{array}{l}\text { Tidak perhatikan dudukan hole fan (motor dan } \\
\text { bracket yang sudah terpasang) bahwa tidak boleh } \\
\text { tertarik }\end{array}$ & Kipas tidak dapat berputar dengan baik \\
\hline & $\begin{array}{l}\text { Mengabaikan dudukan hole fan bahwa tidak boleh } \\
\text { patah }\end{array}$ & Kipas tidak dapat berputar dengan baik \\
\hline & $\begin{array}{l}\text { Mengabaikan dudukan hole fan bahwa tidak boleh } \\
\text { miring }\end{array}$ & Kipas tidak dapat berputar dengan baik \\
\hline & $\begin{array}{l}\text { Mengabaikan pemeriksaan pengait kabel motor } \\
\text { bahwa tidak boleh patah }\end{array}$ & $\begin{array}{l}\text { Kabel berantakan, Kipas tidak dapat berputar } \\
\text { (macet) }\end{array}$ \\
\hline & $\begin{array}{l}\text { Tidak perhatikan pengait kabel motor bahwa tidak } \\
\text { boleh tertarik }\end{array}$ & Kabel putus, kipas tidak dapat berputar \\
\hline & $\begin{array}{l}\text { Tidak perhatikan di area sekitar pengait kabel } \\
\text { bahwa tidak boleh ada flash }\end{array}$ & $\begin{array}{l}\text { Ada gesekan antara kabel, kabel bisa mengelupas, } \\
\text { kipas tidak dapat berputar }\end{array}$ \\
\hline & Jumlah sekrup tidak sesuai & Motor dan bracket tidak terpasang dengan kuat \\
\hline & $\begin{array}{l}\text { Tidak perhatikan rakitan kipas bahwa tidak boleh } \\
\text { mengelupas }\end{array}$ & $\begin{array}{l}\text { Kipas tidak berputar dengan baik, timbul bunyi } \\
\text { (noise) }\end{array}$ \\
\hline & $\begin{array}{l}\text { Tidak perhatikan rakitan kipas bahwa tidak boleh } \\
\text { miring }\end{array}$ & Kipas tidak dapat berputar (macet) \\
\hline & $\begin{array}{l}\text { Tidak perhatikan rakitan kipas bahwa tidak boleh } \\
\text { patah }\end{array}$ & Kipas tidak dapat berputar (macet) \\
\hline & $\begin{array}{l}\text { Tidak periksa bagian hole tempat rakitan kipas } \\
\text { bahwa tidak boleh ada flash }\end{array}$ & $\begin{array}{l}\text { Dapat menimbukan adanya noise karena adanya } \\
\text { gesekan antara kipas dengan flash yang tidak ter- } \\
\text { buang }\end{array}$ \\
\hline & $\begin{array}{l}\text { Tidak periksa bagian hole tempat rakitan kipas } \\
\text { bahwa tidak boleh over cut }\end{array}$ & $\begin{array}{l}\text { Kipas tidak terpasang dengan benar, adanya angin } \\
\text { berlebih yang dapat menimbulkan bunga es pada } \\
\text { kulkas }\end{array}$ \\
\hline & $\begin{array}{l}\text { Tidak melakukan pengetesan kipas pada jig untuk } \\
\text { memastikan kipas berputar atau tidak }\end{array}$ & $\begin{array}{l}\begin{array}{l}\text { Kipas tidak berputar, kualitas shroud buruk, } \\
\text { shroud dikembalikan }\end{array} \\
\end{array}$ \\
\hline & $\begin{array}{l}\text { Mengabaikan bunyi (noise) pada kipas saat dites } \\
\text { berputar }\end{array}$ & $\begin{array}{l}\text { Timbul noise pada saat kipas berputas, memancing } \\
\text { timbulnya bunga es pada kulkas }\end{array}$ \\
\hline \multirow{3}{*}{ Finishing Shroud } & $\begin{array}{l}\text { Mengikat kabel-kabel pengait pada motor dengan } \\
\text { menggunakan tali tirup dengan asal-asalan }\end{array}$ & $\begin{array}{l}\text { Kabel berantakan, kabel bisa tertarik lalu putus, } \\
\text { menyebabkan shroud tidak dapat berfungsi de- } \\
\text { ngan baik }\end{array}$ \\
\hline & $\begin{array}{l}\text { Lupa memotong tali tirup yang terlalu pan- } \\
\text { jang pada ikatan dengan menggunakan gunting } \\
\text { khusus }\end{array}$ & $\begin{array}{l}\text { Tali tirup terjuntai berantakan, bisa menimbulkan } \\
\text { goresan pada bidang shroud }\end{array}$ \\
\hline & $\begin{array}{l}\text { Mengabaikan pemeriksaan kembali ikatan kabel } \\
\text { pengait jangan sampai kabel yang keluar }\end{array}$ & $\begin{array}{l}\text { Kabel berantakan, kabel bisa tertarik lalu putus, } \\
\text { menyebabkan shroud tidak dapat berfungsi den- } \\
\text { gan baik }\end{array}$ \\
\hline \multirow{4}{*}{ Packing Shroud } & Menyusun shroud dengan asal-asalan & $\begin{array}{l}\text { Susunan shroud berantakan, bisa menimbulkan } \\
\text { gesekan antar shroud yang dapat menimbulkan } \\
\text { cacat }\end{array}$ \\
\hline & $\begin{array}{l}\text { Tidak menyesuaikan jumlah shroud pada ukuran } \\
\text { kardus atau rak trolley }\end{array}$ & $\begin{array}{l}\text { Susunan shroud tidak rapi, terjadi penumpukan, } \\
\text { bisa menimbulkan gesekan antar shroud yang da- } \\
\text { pat menimbulkan cacat }\end{array}$ \\
\hline & $\begin{array}{l}\text { Tidak mengikat kardus atau trolley dengan tali } \\
\text { khusus }\end{array}$ & $\begin{array}{l}\text { Susunan shroud bisa bergerak, shroud bisa jatuh } \\
\text { dari rak trolley }\end{array}$ \\
\hline & Tidak memberi label pada kardus atau trolley & $\begin{array}{l}\text { Produk tidak dikenali tanggal produksinya, } \\
\text { shroud bisa jatuh dari rak trolley }\end{array}$ \\
\hline
\end{tabular}


salnya untuk EPC tingkat disiplin pekerja yang rendah dengan Total Heart Effect 1.2 (Lihat tabel 2) dan Assessed Proportion 0.6 maka nilai Assessed Effect nya adalah 1.12. Kemudian untuk menghitung HEP nya adalah dengan cara mengalikan masingmasing Assessed Effect dengan Nominal Human Unreliability, contoh : nilai Assessed Effect yang didapat adalah 1.12 dan 1.03. Dengan Nominal Human Unreliability sebesar 0.02. Maka nilai HEP nya adalah 0.023072

Dari perhitungan yang telah dilakukan dengan menggunakan Metode HEART (Human Error And Reliability Technique) maka rekapitulasi hasil perhitungan yang didapatkan adalah seperti yang tercantum dalam tabel 4 .

Diketahui dari tabel rekapitulasi, nilai HEP (Human Error Probability) yang terbesar adalah HEP tidak melakukan sisip area flash menggunakan pisau dengan hati-hati dengan nilai sebesar 0.53424. Pekerjaan ini tidak dilakukan dikarenakan waktu yang singkat sehingga operator lupa dan tergesa-gesa untuk melakukan tugas ini, operator yang kurang berpengalaman, dan kurangnya kedisiplinan kerja sehingga operator melalaikan tugasnya.

Kesalahan yang ditemukan tidak sepenuhnya memperlihatkan bahwa sisi flash benar-benar tidak disisip, tetapi sisi-sisi flash tetap disisip hanya saja hasil penyisipannya sangat berantakan dan tidak teratur. Ada pula flash yang disisip namun hasilnya overcut, dan ada sisi yang disisip namun masih ditemukannya flash, dan ada juga yang tidak menyisip flash sama sekali.

Penyisipan flash sangat penting dilakukan, karena jika flash yang umumnya berada di bagian sisi bidang shroud, lubang hole fan, dan pengait kabel motor tidak disisip maka ketika shroud dirakit beserta komponen yang lain menjadi tidak pas. Pada rakitan kipas dapat menimbulkan bunyi berdesis (noise). Adanya flash juga dapat menimbulkan kecelakaan pada penggunanya seperti luka tergores atau terpotong. Selain itu jika pemotongan flash berlebihan akan menimbulkan adanya overcut. Akibat dari adanya overcut adalah timbulnya bunga es pada kulkas.

\section{Kesimpulan}

Kesalahan operator yang tidak menyisip sisi flash bidang shroud dengan hati-hati menjadi penyebab utama dari cacat produk shroud berdasarkan nilai HEPnya yaitu sebesar 0.53424. Faktor inilah yang mengakibatkan perusahaan
Tabel 4: Rekapitulasi Hasil HEP (Human Error Probability)

\begin{tabular}{|c|c|c|}
\hline No & Kegagalan Tugas (Possible Error) & HEP \\
\hline 1 & $\begin{array}{c}\text { Tidak memperhatikan warna harus } \\
\text { sesuai dengan approval }\end{array}$ & 0.023072 \\
\hline 2 & $\begin{array}{c}\text { Tidak memeriksa apa ada yang } \\
\text { short material }\end{array}$ & 0.037632 \\
\hline 3 & Tidak memeriksa adanya silver & 0.037632 \\
\hline 4 & $\begin{array}{l}\text { Tidak memeriksa adanya } \\
\text { legok/sink mark }\end{array}$ & 0.037632 \\
\hline 5 & Tidak memeriksa adanya belang & 0.037632 \\
\hline 6 & $\begin{array}{l}\text { Tidak memeriksa adanya baret } \\
\text { (scratch) }\end{array}$ & 0.037632 \\
\hline 7 & $\begin{array}{l}\text { Tidak memeriksa adanya wild line } \\
\text { (sambungan bahan) }\end{array}$ & 0.037632 \\
\hline 8 & $\begin{array}{l}\text { Tidak menyisip area flash dengan } \\
\text { pisau dengan hati-hati }\end{array}$ & 0.53424 \\
\hline 9 & $\begin{array}{c}\text { Tidak memeriksa apa ada area } \\
\text { yang overcut }\end{array}$ & 0.16128 \\
\hline 10 & $\begin{array}{c}\text { Tidak memeriksa apakah foam } \\
\text { mengelupas }\end{array}$ & 0.04554 \\
\hline 11 & $\begin{array}{c}\text { Tidak memeriksa apakah foam } \\
\text { tertarik }\end{array}$ & 0.043125 \\
\hline 12 & $\begin{array}{l}\text { Tidak memberi tanda marking } \\
\text { inisial operator, tanggal, dan shift }\end{array}$ & 0.06496 \\
\hline 13 & $\begin{array}{c}\text { Tidak memeriksa tipe komponen } \\
\text { sesuai dengan Shroud yang akan } \\
\text { dibuat }\end{array}$ & 0.02835756 \\
\hline 14 & $\begin{array}{l}\text { Merakit komponen tidak sesuai } \\
\text { dengan urutan }\end{array}$ & 0.027258 \\
\hline 15 & $\begin{array}{c}\text { Tidak perhatikan dudukan hole fan } \\
\text { (motor dan bracket yang sudah } \\
\text { terpasang) bahwa tidak boleh } \\
\text { tertarik }\end{array}$ & 0.0747648 \\
\hline 16 & $\begin{array}{l}\text { Mengabaikan dudukan hole fan } \\
\text { bahwa tidak boleh patah }\end{array}$ & 0.054516 \\
\hline 17 & $\begin{array}{l}\text { Mengabaikan dudukan hole fan } \\
\text { bahwa tidak boleh miring }\end{array}$ & 0.063888 \\
\hline 18 & $\begin{array}{c}\text { Mengabaikan pemeriksaan pengait } \\
\text { kabel motor bahwa tidak boleh } \\
\text { patah }\end{array}$ & 0.00726 \\
\hline 19 & $\begin{array}{l}\text { Tidak perhatikan pengait kabel } \\
\text { motor bahwa tidak boleh tertarik }\end{array}$ & 0.0124608 \\
\hline 20 & $\begin{array}{c}\text { Tidak perhatikan di area sekitar } \\
\text { pengait kabel bahwa tidak boleh } \\
\text { ada flash }\end{array}$ & 0.005088 \\
\hline 21 & Jumlah sekrup tidak sesuai & 0.0015376 \\
\hline 22 & $\begin{array}{l}\text { Tidak perhatikan rakitan kipas } \\
\text { bahwa tidak boleh mengelupas }\end{array}$ & 0.015576 \\
\hline 23 & $\begin{array}{l}\text { Tidak perhatikan rakitan kipas } \\
\text { bahwa tidak boleh miring }\end{array}$ & 0.020328 \\
\hline 24 & $\begin{array}{l}\text { Tidak perhatikan rakitan kipas } \\
\text { bahwa tidak boleh patah }\end{array}$ & 0.017976 \\
\hline 25 & $\begin{array}{c}\text { Tidak periksa bagian hole tempat } \\
\text { rakitan kipas bahwa tidak boleh } \\
\text { ada flash }\end{array}$ & 0.207 \\
\hline 26 & $\begin{array}{c}\text { Tidak periksa bagian hole tempat } \\
\text { rakitan kipas bahwa tidak boleh } \\
\text { over cut }\end{array}$ & 0.1888 \\
\hline 27 & $\begin{array}{c}\text { Tidak melakukan pengetesan kipas } \\
\text { pada jig untuk memastikan kipas } \\
\text { berputar atau tidak }\end{array}$ & 0.0071232 \\
\hline 28 & $\begin{array}{l}\text { Mengabaikan bunyi (noise) pada } \\
\text { kipas saat dites berputar }\end{array}$ & 0.298496 \\
\hline 29 & $\begin{array}{l}\text { Mengikat kabel-kabel pengait pada } \\
\text { motor dengan menggunakan tali } \\
\text { tirup dengan asal-asalan }\end{array}$ & 0.0108416 \\
\hline 30 & $\begin{array}{l}\text { Lupa memotong tali tirup yang } \\
\text { terlalu panjang pada ikatan dengan } \\
\text { menggunakan gunting khusus }\end{array}$ & 0.0094864 \\
\hline 31 & $\begin{array}{l}\text { Mengabaikan pemeriksaan kembali } \\
\text { ikatan kabel pengait jangan sampai } \\
\text { kabel yang keluar }\end{array}$ & 0.07683984 \\
\hline 32 & $\begin{array}{l}\text { Menyusun shroud dengan } \\
\text { asal-asalan }\end{array}$ & 0.0274428 \\
\hline 33 & $\begin{array}{c}\text { Tidak menyesuaikan jumlah } \\
\text { shroud pada ukuran kardus atau } \\
\text { rak trolley }\end{array}$ & 0.063525 \\
\hline 34 & $\begin{array}{l}\text { Tidak mengikat kardus atau trolley } \\
\text { dengan tali khusus }\end{array}$ & 0.00726 \\
\hline 35 & $\begin{array}{c}\text { Tidak memberi label pada kardus } \\
\text { atau trolley }\end{array}$ & 0.0090024 \\
\hline
\end{tabular}


mengalami kerugian akibat penalti dari konsumen.

\section{Daftar Pustaka}

Bell, Julie \& Justin Holroyd. (2009). "Review of human reliability assessment methods", Health and Safety Laboratory. Tersedia di http://www.hse.gov.uk/research/rrpdf/rr67 9.pdf. Diakses pada 7 Juni 2014.

Dix, A., Janet, F., Gregory D. Abowd \& Russell B. (2009). Human Computer Interaction. Third Edition. Pearson Education Limited).

Love, P. and Josephson, P. (2004). "Role of ErrorRecovery Process in Projects". Journal of Management Engineering.

Peters, B.J \& George A. Peters. (2006). Human Error: Causes and Control. CRC Press LLC).

Stanton, Neville. (2005). Handbook Of Human Factors And Ergonomic Methods. CRC Press : Florida 